\title{
APRESENTAÇÃO DO NÚMERO
}

Cláudio Zanini (UFCSPA) Júlio França (UERJ)

Howard Philips Lovecraft é um dos mais influentes escritores de horror, de ficção científica, de fantasia ou, simplesmente, em seus termos, Weird Fiction, da primeira metade do século XX. A importância de sua obra pode ser medida tanto pela quantidade e qualidade de artistas que Ihe são tributários - Stephen King, Clive Barker, Ridley Scott, Guillermo Del Toro, John Carpenter, Alan Moore, Neil Gaiman, H. R. Giger - quanto pela presença disseminada de suas criações na cultura popular contemporânea.

Em homenagem aos seus 80 anos de morte, e em celebração ao centenário de uma de suas narrativas mais emblemáticas, "Dagon", a Revista Abusões dedica seu quarto número à produção artística e crítica do escritor norte-americano. A amplitude dos temas e das abordagens contidas nos artigos, nas entrevistas e no romance gráfico que se seguem, confirma a pujança da obra lovecraftiana e sua presença, viva e inquietante, no imaginário do mundo contemporâneo.

Apesar de sua curta vida - ele faleceu aos 46 anos, em 1937 -, Lovecraft teve uma das mais prolíficas carreiras literárias de que se tem notícia. Além de inúmeras cartas escritas a seus pares e leitores, nas quais debateu temas tais como literatura, política e sociedade, ele escreveu incontáveis textos para jornais, dezenas de 
narrativas ficcionais e o ensaio O Horror Sobrenatural na Literatura, texto seminal para estudiosos do gótico, do fantástico, do insólito, do maravilhoso e do horror.

Criador de diferentes universos ficcionais, Lovecraft foi e ainda é um escritor paradoxal: inventivo ao ponto de criar novos povos em mundos, ele acreditava na supremacia de uma raça sobre as outras; conservador, explorou com entusiasmo inovações científicas e tecnológicas em sua ficção; criador de toda sorte de monstruosidades alienígenas e sobrenaturais, Lovecraft descreveu como poucos sensações fundamentalmente humanas, tais como o medo, a angústia existencial e a ambição por conhecimento.

Nas próximas páginas, algumas respostas serão dadas, muitas novas perguntas serão propostas à instigante e contraditória obra lovecraftiana. Convidamos o leitor da Revista Abusões a se aventurar nesse esforço de apreciação e de entendimento a um dos ficcionistas mais desafiadores do século $X X$. 